\title{
Disinfestation of Sitophilus zeamais Motschulsky in stored maize using microwave
}

\author{
Ravipat Lapcharoensuk ${ }^{1 *}$, Sattawat Wisetsri ${ }^{2}$, and Supattra Meesuk ${ }^{2}$ \\ ${ }^{1}$ King Mongkut's Institute of Technology Ladkrabang, Faculty of Engineering, Department of \\ Agricultural Engineering, Post Harvest Innovation Research and Development Laboratory, Bangkok, \\ Thailand \\ ${ }^{2}$ Rajamangala University of Technology Tawan-ok, Faculty of science and technology, Division of \\ Agricultural Engineering, Chonburi, Thailand
}

\begin{abstract}
This study aimed primarily to investigate on disinfestation of maize weevil (Sitophilus zeamais Motschulsky) in maize storage by using microwave method. Specimens of Maize weevils were cultured for 30 days in a maize sample with $17 \%$ moisture content (wet basis). Several different life stages of the maize weevil (egg, young larva, old larva, pupa and adult) were then infested in the sample. Next, the maize sample was exposed to 200,300 and $450 \mathrm{~W}$ of microwave power for 60,120 and $180 \mathrm{~s}$, and the number of weevils were counted after each treatment. Moreover, the sample was kept for another 2 months to see whether the eggs have survived the treatment and grown to be adults. In addition, the effects of the level of microwave power and exposure time on the property of the maize sample were observed. The quality parameters investigated were moisture content, colour and protein and fat contents. It was found that, at $300 \mathrm{~W}$ of power for $180 \mathrm{~s}$, the microwave was able to disinfect weevils at all life stages successfully, while the quality of the maize sample did not change significantly at the tested microwave settings and exposure times, except for the protein content. These findings indicate that microwave can be a good alternative to harmful chemical methods for disinfestation of maize weevils.
\end{abstract}

\section{Introduction}

Maize (Zea mays L.; MZ) is the most important foods and feed cereal crops of the world like rice and wheat. Maize grains are made into many different products such as flour, syrup, beverage and animal feed. For the feed industry, maize is the most important component in an animal feed product because the seeds provide essential nutrients for animals. Maize in bulk are usually stored in a silo for about 1-2 months waiting to be transferred into a feed processing step. During storage, maize is always damaged by some maize weevils especially Sitophilus zeamais Motschulsky. Maize weevil is the most damaging post-harvest storage pest of maize. Infestation of maize weevils starts in the field and severe damage is done during storage [1-3]. Maize weevil infestation causes broken grains which decreases their market values. Moreover, flying weevils annoy workers at a feed manufacturing plant. Two

* Corresponding author: ravipat.la@kmitl.ac.th 
previous studies reported a grain weight loss of about $20-90 \%$ due to an infestation of maize weevils [4-5].

Methyl bromide has often been used to disinfest maize weevils in many countries. However, it is an ozone-depleting substance (ODS), and several environmental agencies have developed strategies to phase out this chemical [6]. Disinfestation of insects in a stored agricultural product by heating has also been studied widely. A variety of heating methods was investigated: fluidized bed [7], radio frequency [8] and hot air [9]. Another interesting heating method for disinfestation is microwave heating method. Microwave radiation can penetrate a bulk material and its alternating electromagnetic field energy can induce polar molecules inside the material and transform into thermal energy. Potentially, disinfestation by using microwave is more efficient than other heating methods. Several previous research reported successful disinfestation of insects in agricultural products by microwave heating: apple [9], date [6, 10], mung bean [11], walnut [12], wheat [13-17] and rice [18]. However, too high a microwave power level can cause irreversible changes in the structure and quality of an agricultural product. Changes in the physical properties and nutritional composition of a product from microwave heating are important indicators of heat processing. Many researchers reported the effect of microwave heating on the quality of an agricultural product such as peanuts [19], sesame seeds [20] and macadamias [21]. Therefore, the quality of maize product after microwave heating was also investigated in this study.

The objectives of this research were the following: (1) to investigate the effect of microwave heating at different power levels and exposure times on the mortality of Sitophilus zeamais Motschulsky in a stored Maize sample; and (2) to investigate the effects of microwave heating on the quality of the maize sample (i.e., moisture content, colour, fat and protein contents).

\section{Materials and methods}

\subsection{Maize sample and weevil culture}

Five kilograms of maize sample were collected randomly from a receiving station in a feed plant (CPF (Thailand) PCL., Sriracha district, Chonburi province, Thailand) and delivered to the laboratory. The maize sample was assessed of its initial quality, i.e., its moisture content, colour, protein and fat contents. The initial moisture content of the maize sample was measured with a grain moisture meter (EE -KU, Kasetsart University, Thailand). The entire maize sample was divided to 27 smaller samples; each of these smaller samples was about $150 \mathrm{~g}$, and it was retained in a plastic zipper bag. Twenty adult weevils (Sitophilus zeamais Motschulsky) were put into each of these bags and reared at $30^{\circ} \mathrm{C}$ and $70 \%$ relative humidity (RH). All maize samples were kept for 30 days in order for the weevils to develop into a population of eggs, young and old larvae and pupae as well as adults of Sitophilus zeamais Motschulsky.

\subsection{Microwave heating}

Before the microwave heating experiment, each maize sample was poured from the plastic zipper bag onto a sieve $(1.68 \mathrm{~mm})$ to separate adult weevils from the maize grains. The number of the adult weevils were counted, and only twenty weevils were then put back into the maize sample. Next, the maize sample together with the 20 adult weevils were put on a $140 \mathrm{~mm}$ petri dish and covered with a lid to capture the weevils. A microwave oven $(230 \mathrm{~V}$, $50 \mathrm{~Hz}$, Model ME-711 K/XST, Samsung Electronics (Thailand) Ltd., Thailand) was used in this study. The oven power could be adjusted to 7 levels $(100,200,300,450,600,700$ and 
$800 \mathrm{~W}$ ), and the microwave radiation was diffused by a turntable. The sample was exposed to microwave heating at 200,300 and $450 \mathrm{~W}$ and 60,120 and $180 \mathrm{~s}$ : each setting was replicated 3 times.

\subsection{Temperature}

The temperatures at the centre of the petri dish and four radial positions were recorded immediately with an infrared thermometer (Model AZ-8868, AZ instruments, Taiwan) after the microwave heating step. The mean temperature from the five locations was then determined.

\subsection{Mortality}

After the immediate sample temperature measurement after heating, the sample was kept at room temperature $\left(25^{\circ} \mathrm{C}\right)$ for about $30 \mathrm{~min}$ to reduce the sample temperature. Survived and dead weevils ware separated from the maize grains with a sieve $(1.68 \mathrm{~mm})$. The number of dead and survived insects were counted by visual inspection to determine the mortality rate of adult weevils. Finally, the sample with possibly survived weevils at various life stages was kept further until 60 days after in order to determine the number of survived eggs, young and old larvae, and pupae at that time.

\subsection{Grain quality measurement}

The moisture content of the sample was measured with a grain moisture tester (EE -KU, Kasetsart University, Thailand). Three grain samples from the bag were randomly collected; their moisture contents were measured; and the mean moisture content of the three samples was recorded.

The colour of the sample was recorded according to the CIE system ( $\mathrm{L}^{*}, \mathrm{a}^{*}, \mathrm{~b}^{*}$ value) with a colorimeter (Colour Reader CR-10, KONICA MINOLTA, Japan). Three grain samples from the bag were randomly collected; their colour parameters were measured; and the mean values of these parameters were recorded.

The relevant nutritional parameters of maize were protein and fat contents which have been widely used in feed factories as indicators of maize quality. The protein and fat contents were determined according to AOAC methods [22]. The nitrogen level $(\mathrm{N})$ was measured by the method of Kjeldahl and the crude protein content was calculated as $\mathrm{N} \times 6.25$. The fat content was evaluated with the Soxtherm method. Both protein and fat contents were recorded as mean values of three replicates of each sample.

\subsection{Data analysis}

The quality of maize samples in all treatments were reported as mean and standard deviation (SD) of triplicates. The statistical significance of the means was determined with Duncan's multiple range tests at $95 \%$ confidence interval $(\mathrm{P}<0.05)$ for the outcomes of the experiment on the effects of microwave level and exposure time on the quality of maize. 


\section{Results and discussion}

The results of average temperature, mortality of adult insects after microwave heating and number of survived adult insects after 2 months in a maize storage are shown in Table 1 . The average temperature of the samples increased with increasing microwave power and exposure time. At $200 \mathrm{~W}$ of microwave power, the mortality of adult insects was almost $0 \%$ except for $180 \mathrm{~s}$ exposure time at 8 bodies. Furthermore, the mortality of adult insects was fully $100 \%$ when the microwave power was increased to $300 \mathrm{~W}$ for all tested exposure times. Jayas et al. [23] suggested that a temperature above $55^{\circ} \mathrm{C}$ is lethal for any insects. In this research, the temperature of the samples reached $62 \pm 5^{\circ} \mathrm{C}$ at $300 \mathrm{~W}$ at an exposure time of $120 \mathrm{~s}$, thus the expected mortality outcome for the weevil adults was obtained. This result was consistent with those from previous research studies on disinfestation of insects on agricultural products by using microwave radiation: Cryptolestes ferrugineus on wheat flour [16-17]; Callosobruchus maculatus on mung bean [11]; Fardh insects on date [6]; Tribolium castaneum on wheat flour [13-15] on rice [18] and Plodia interpunctella on wheat germ [24]. All of them reported that $100 \%$ of insect mortality was obtained when the agricultural product temperature was over $55^{\circ} \mathrm{C}$. Therefore, a suitable microwave power and exposure time can be optimally selected for insect disinfestation by monitoring the temperature of the agricultural product. Found in this study, the number of survived weevil adults after 2 months in the maize storage decreased with increasing microwave power and exposure time. The percentage of survived weevil adults was $0 \%$ when the samples were irradiated with $300 \mathrm{~W}$ of microwave for $180 \mathrm{~s}$ or $450 \mathrm{~W}$ for $60 \mathrm{~s}, 120 \mathrm{~s}$ and $180 \mathrm{~s}$. These results indicate that microwave can disinfest eggs, young and old larvae and pupae of Sitophilus zeamais Motschulsky effectively.

Table 1. Average temperature of maize samples, mortality of adult insects after microwave heating and number of adult insects after 2 months in a maize storage.

\begin{tabular}{|c|c|c|c|c|c|}
\hline \multirow[t]{2}{*}{$\begin{array}{l}\text { Power } \\
\text { (Watt) }\end{array}$} & \multirow[t]{2}{*}{$\begin{array}{c}\text { Exposure time } \\
\text { (s) }\end{array}$} & \multirow{2}{*}{$\begin{array}{c}\text { Average } \\
\text { temperature } \\
\left({ }^{\circ} \mathrm{C}\right)\end{array}$} & \multirow{2}{*}{$\begin{array}{l}\text { Mortality of } \\
\text { adult weevil } \\
\quad \text { (body) }\end{array}$} & \multicolumn{2}{|c|}{$\begin{array}{c}\text { Number of adult weevils in } \\
\text { the maize storage (number of } \\
\text { insects) }\end{array}$} \\
\hline & & & & 1 month & 2 months \\
\hline \multirow[t]{3}{*}{200} & 60 & $35 \pm 3$ & $0 \pm 0$ & $80 \pm 4$ & $208 \pm 6$ \\
\hline & 120 & $44 \pm 2$ & $0 \pm 0$ & $72 \pm 2$ & $123 \pm 4$ \\
\hline & 180 & $46 \pm 6$ & $8 \pm 2$ & $62 \pm 2$ & $153 \pm 6$ \\
\hline \multirow[t]{3}{*}{300} & 60 & $43 \pm 2$ & $6 \pm 2$ & $75 \pm 4$ & $182 \pm 7$ \\
\hline & 120 & $62 \pm 5$ & $20 \pm 0$ & $3 \pm 1$ & $25 \pm 4$ \\
\hline & 180 & $87 \pm 4$ & $20 \pm 0$ & $0 \pm 0$ & $0 \pm 0$ \\
\hline \multirow[t]{3}{*}{450} & 60 & $62 \pm 6$ & $20 \pm 0$ & $0 \pm 0$ & $0 \pm 0$ \\
\hline & 120 & $87 \pm 3$ & $20 \pm 0$ & $0 \pm 0$ & $0 \pm 0$ \\
\hline & 180 & $95 \pm 4$ & $20 \pm 0$ & $0 \pm 0$ & $0 \pm 0$ \\
\hline
\end{tabular}

The results of the quality of maize after microwave heating are shown in Table 2 . The moisture content of unheated maize was $17.3 \pm 0.92 \%$, while that of the heated samples was around $12.50 \pm 0.43 \%$. The moisture content decreased dramatically with increasing microwave power and exposure time. The percentage of moisture loss was in the range of $2.24-28 \%$, indicating that microwave radiation has a good potential for disinfesting weevils and drying maize at the same time. The colour values - $\mathrm{L}^{*}, \mathrm{a}^{*}$ and $\mathrm{b}^{*}$ - of the maize samples measured before microwave heating were $62.2 \pm 4.2,13.2 \pm 1.9$ and $33.9 \pm 3.7$, respectively. The colour of the maize did not change significantly with increasing power level and exposure time in the ranges tested, indicating that microwave can be applied to disinfest Sitophilus zeamais Motschulsky without changing the colour of the maize. The average protein content of the unheated maize samples was $5.4 \pm 0.1 \%$. 
Table 2. Quality metrics of maize samples subjected to various microwave power levels and exposure times.

\begin{tabular}{|c|c|c|c|c|c|c|c|}
\hline \multirow{2}{*}{$\begin{array}{l}\text { Power } \\
\text { (Watt) }\end{array}$} & \multirow{2}{*}{$\begin{array}{c}\text { Exposure } \\
\text { time } \\
\text { (s) }\end{array}$} & \multirow{2}{*}{$\begin{array}{c}\text { Moisture } \\
\text { content } \\
(\%)\end{array}$} & \multicolumn{3}{|c|}{ Colour } & \multirow{2}{*}{$\begin{array}{l}\text { Protein } \\
\text { (\%) }\end{array}$} & \multirow{2}{*}{$\begin{array}{l}\text { Fat } \\
(\%)\end{array}$} \\
\hline & & & $\mathbf{L}^{*}$ & $a^{*}$ & $\mathbf{b}^{*}$ & & \\
\hline \multicolumn{2}{|c|}{ Unheated sample } & $17.30 \pm 0.92^{\mathrm{a}}$ & $62.2 \pm 4.2^{\mathrm{a}}$ & $13.2 \pm 1.9^{\mathrm{a}}$ & $33.9^{2} \pm 3.7^{\mathrm{a}}$ & $5.4 \pm 0.1^{\mathrm{b}}$ & $3.68 \pm 0.08^{\mathrm{a}}$ \\
\hline \multirow{3}{*}{200} & 60 & $15.97 \pm 0.82^{\mathrm{a}}$ & $65.2 \pm 1.6^{\mathrm{a}}$ & $9.9 \pm 1.1^{\mathrm{a}}$ & $31.0 \pm 1.2^{\mathrm{a}}$ & $5.4 \pm 0.2^{b}$ & $3.45 \pm 0.09^{\mathrm{a}}$ \\
\hline & 120 & $15.97 \pm 0.09^{\mathrm{a}}$ & $63.8 \pm 0.3^{\mathrm{a}}$ & $13.2 \pm 2.3^{\mathrm{a}}$ & $34.2 \pm 3.8^{\mathrm{a}}$ & $5.3 \pm 0.2^{b}$ & $3.42 \pm 0.04^{\mathrm{a}}$ \\
\hline & 180 & $16.87 \pm 0.37^{\mathrm{a}}$ & $64.3 \pm 2.9^{\mathrm{a}}$ & $18.7 \pm 1.1^{\mathrm{a}}$ & $43.7 \pm 1.6^{\mathrm{a}}$ & $4.8 \pm 0.1^{\mathrm{b}}$ & $3.35 \pm 0.02^{\mathrm{a}}$ \\
\hline \multirow{3}{*}{300} & 60 & $14.37 \pm 0.09^{\mathrm{a}}$ & $58.7 \pm 5.5^{\mathrm{a}}$ & $13.9 \pm 3.1^{\mathrm{a}}$ & $34.1 \pm 4.3^{\mathrm{a}}$ & $4.8 \pm 0.1^{\mathrm{a}}$ & $3.33 \pm 0.07^{\mathrm{a}}$ \\
\hline & 120 & $13.77 \pm 0.34^{\mathrm{a}}$ & $59.4 \pm 2.3^{\mathrm{a}}$ & $14.3 \pm 3.1^{\mathrm{a}}$ & $39.1 \pm 5.4^{\mathrm{a}}$ & $4.7 \pm 0.0^{\mathrm{a}}$ & $3.34 \pm 0.08^{\mathrm{a}}$ \\
\hline & 180 & $12.50 \pm 0.43^{\mathrm{a}}$ & $54.8 \pm 8.9^{a}$ & $16.1 \pm 2.2^{\mathrm{a}}$ & $38.3 \pm 2.2^{\mathrm{a}}$ & $4.7 \pm 0.2^{\mathrm{a}}$ & $3.36 \pm 0.07^{\mathrm{a}}$ \\
\hline \multirow{3}{*}{450} & 60 & $13.23 \pm 0.47^{\mathrm{a}}$ & $63.9 \pm 3.7^{\mathrm{a}}$ & $16.5 \pm 1.9^{\mathrm{a}}$ & $37.6 \pm 2.8^{\mathrm{a}}$ & $4.6 \pm 0.2^{\mathrm{a}}$ & $3.41 \pm 0.05^{\mathrm{a}}$ \\
\hline & 120 & $12.97 \pm 0.47^{\mathrm{a}}$ & $63.7 \pm 2.3^{\mathrm{a}}$ & $16.2 \pm 2.1^{\mathrm{a}}$ & $40.7 \pm 3.9^{\mathrm{a}}$ & $4.6 \pm 0.2^{\mathrm{a}}$ & $3.33 \pm 0.05^{\mathrm{a}}$ \\
\hline & 180 & $12.63 \pm 0.90^{\mathrm{a}}$ & $62.8 \pm 4.6^{\mathrm{a}}$ & $12.1 \pm 2.4^{\mathrm{a}}$ & $37.6 \pm 3.2^{\mathrm{a}}$ & $4.6 \pm 0.1^{\mathrm{a}}$ & $3.47 \pm 0.06^{\mathrm{a}}$ \\
\hline
\end{tabular}

The means that share the same letter in a column are not significantly different $(p>0.05)$ from each other.
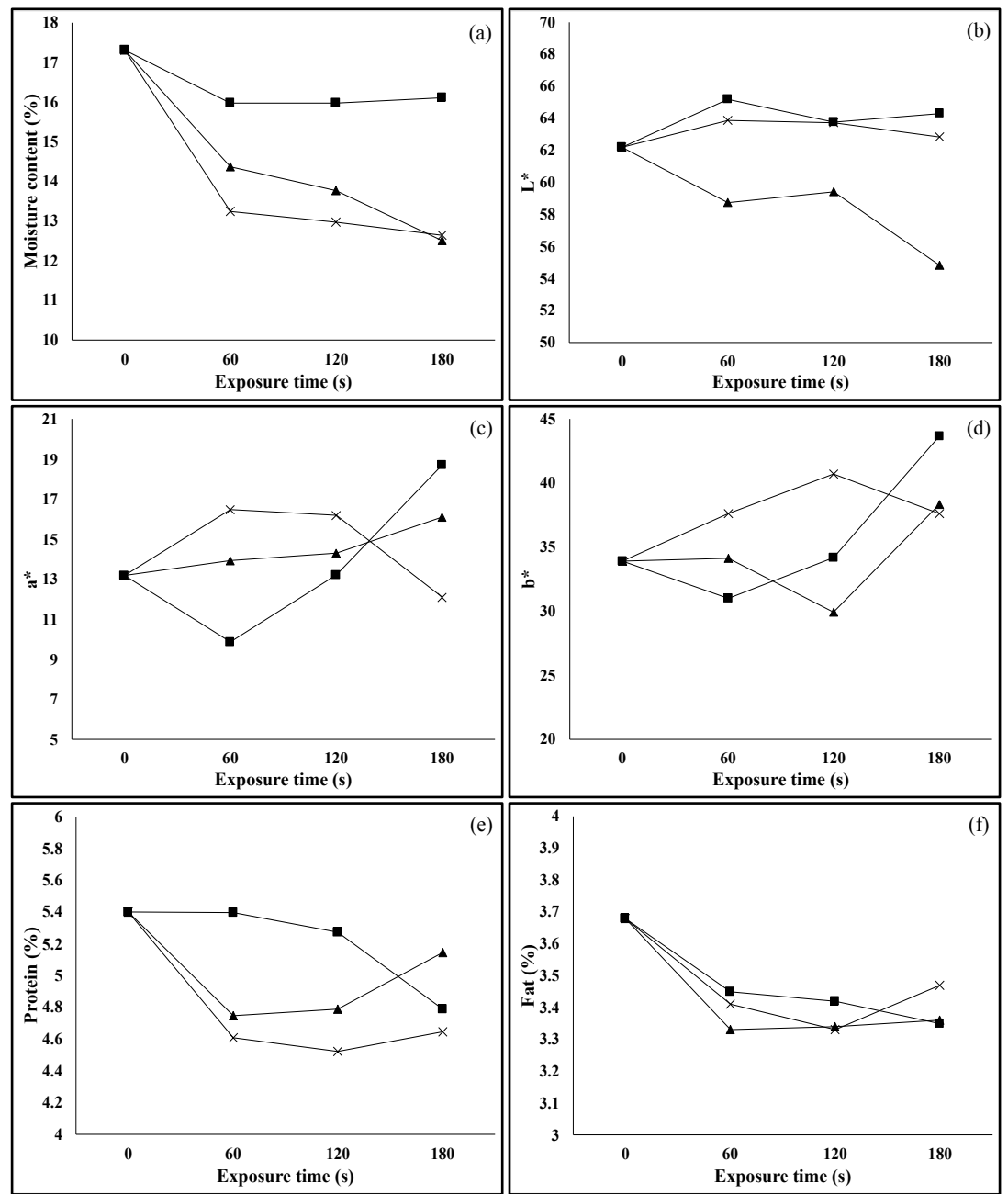

Fig. 1. Scatter plots of quality metrics of maize subjected to various microwave power levels 200 (匹), $300(\mathbf{\Delta}), 450(\times)$ and exposure times. 
With an increase in exposure time from 60 to $180 \mathrm{~s}$, there were statistically significant decreases in protein content from $5.4 \pm 0.1 \%$ to $4.8 \pm 0.1 \%, 4.7 \pm 0.2 \%$ and $4.6 \pm 0.1 \%$ with 200 , 300 and $450 \mathrm{~W}$ microwave irradiation, respectively. The initial fat content of the untreated maize was $3.68 \pm 0.08 \%$. The fat content of the treated maize was 3.33-3.47 and no significant difference was noted among the different microwave heating settings. The maize quality as shown in the scattered plots in Figure 1 depended on microwave power levels and exposure times. As expected, there was a decrease in moisture and protein contents of maize with increasing power level and treatment time.

\section{Conclusions}

Microwave has a good potential for disinfesting eggs, young and old larvae and pupae of Sitophilus zeamais Motschulsky. All quality metrics of maize did not change significantly with microwave power and exposure time, except protein content. These findings indicate that microwave can be used as an alternative to hazardous chemical methods for successful disinfestation of maize weevils.

\section{References}

1. R.Suleiman, K. Rosentrater, Current maize production, postharvest losses and the risk of mycotoxins contamination in tanzania, in Proceeding of ASABE Annual International Meeting, 26-29 July 2015, New Orleans, LA, United States (2015)

2. R. Suleiman, D. Williams, A. Nissen, C.J. Bern, K.A. Rosentrater, J. Stored Prod. Res. 60, 19-24 (2015)

3. A. Fikremariam, T. Tadele, M. Stephen, B. Yoseph, V. Stefan, Afr. J. Biotechnol. 8, (2009)

4. M. Simbarashe, C. James, M. Benny, Agriculture, Forestry and Fisheries, 2(5), 196-201 (2013)

5. D.P. Giga, S. Mutemerewa, G. Moya, D. Neeley, Crop Prot. 10, 287-292 (1991)

6. A. Manickavasagan, P.M.K. Alahakoon, T.K. Al-Busaidi, S. Al-Adawi, D.S. Jayas, J. Stored Prod. Res. 55, 1-5 (2013)

7. T. Madhiyanon, A. Techaprasan, S. Soponronnarit, Int. J. Heat Mass Transfer 49(1314), 2277-2290 (2006)

8. Z. Liyang, W. Shaojin, J. Stored Prod. Res. 65, 40-47 (2016)

9. T.V. Gamage, P. Sanguansri, P. Swiergon, M. Eelkema, K. Knoerzer, Innov. Food Sci. Emerg. Technol. 29, 261-270 (2015)

10. A. Ben-lalli, P. Bohuon, A. Collignan, J.M. Méot, J. Food Eng. 116(2), 505-514, (2013)

11. P. Purohit, D.S. Jayas, B.K. Yadav, V. Chelladurai, N. D. G., White, J. Stored Prod. Res. 53, 19-22 (2013)

12. I. Das, N.G. Shah, G. Kumar, J. Stored Prod. Res. 59, 152-157 (2014)

13. H. Lu, J. Zhou, S. Xiong, S.Zhao, J. Insect Physiol. 56(9), 1356-1361 (2010)

14. S.M. El-Naggar, A.A. Mikhaiel, J. Stored Prod. Res. 47(3), 191-196 (2011)

15. R. Vadivambal, D.S. Jayas, N.D.G. White, J. Stored Prod. Res. 43(4), 508-514 (2007)

16. F. Jian, D.S. Jayas, N.D.G. White, P.G. Fields, and N. Howe, BIOSYST. ENG. 130, 112 (2015) 
17. F. Jian, S. Doak, D. S. Jayas, P.G. Fields, N.D.G. White, J. Stored Prod. Res. 69, 138142, (2016)

18. S. Zhao, C. Qiu, S. Xiong, X. Cheng, J. Stored Prod. Res. 43(4), 430-434 (2007)

19. B. Cammerer, L.W. Kroh, LWT-Food Sci. Technol. 42, 545-549 (2009)

20. T. Kahyaoglu, S. Kaya, J. Food Eng. 75, 167-177 (2006)

21. M.M. Wall, and T.S. Gentry, LWT -Food Sci. Technol. 40, 587-593 (2007)

22. D. Pearson, Chemical Analysis of Foods 7th Ed. (UK: Church Hill Livingstone, 1976)

23. D.S. Jayas, N.D.G. White, W.E. Muir, Stored Grain Ecosystems (New York, US: Marcel Dekker Inc, 1995)

24. N. Shayesteh, N. N. Barthakur, J. Stored Prod. Res. 32(3), 239-249 (1996) 